\title{
TRADE GLOBALIZATION AND SOCIAL SPENDING IN SPAIN, 1850-2000
}

Sergio Espuelas 
Title: Trade globalization and social spending in Spain, 1850-2000

Abstract: Between 1850 and 2005, Spain experienced major changes in its trade orientation, combining periods of intense trade protectionism with periods of high trade openness. What was the impact on social spending? The econometric results suggest that globalization effect in 1850-2000 Spain has been conditional on fiscal capacity. When fiscal capacity has been high, trade openness has had a positive effect. However, when fiscal capacity has been low, trade-openness effect on social spending has been negative. The results are robust to alternative measures of fiscal capacity and consistent with a placebo test. This would explain why after the 1960s social spending in Spain increased in parallel with trade openness, whereas before that date social spending grew (slowly) in a context of increasing trade protectionism. Thus, both the compensation effect and the race to the bottom find empirical support but the final outcome depends on the fiscal context.

JEL Codes: N3, H5, F68

Keywords: Social spending, trade openness, globalization, Spain

Authors:

Sergio Espuelas

Universitat de Barcelona

Email: sergio.espuelas@ub.edu

Date: October 2021

Acknowledgements: I thank Alfonso Herranz, Concha Betrán, Daniel Gallardo-Albarrán, Daniel Tirado, Henric Häggqvist, J.I. Conde-Ruíz, Ma Ángeles Pons, Michiel de Haas, Paola Azar, Peter Lindert, Pim de Zwart, Xabier García, and the participants at the RHI seminar (Wageningen), XVIII World Economic History Congress, 13th European Historical Economics Society Conference, 7th Jornadas Uruguayas de Historia Económica, and IX Iberometric Conference for their comments. As usual, all remaining errors are my own. Financial support from the Ramón Areces Foundation and the research project PGC2018095821-B-I00 (MINECO/FEDER, UE) is acknowledged. 


\section{Introduction}

There has been much debate about the impact of globalization on the welfare state, in both academia and general public debates. In the academic field, however, there is no consensus yet on whether this impact is positive or negative. Some theories, like Rodrik (1998)'s compensation hypothesis, predict a positive impact. In economies highly exposed to international trade, increased external risk and economic volatility may led to growing demands for social protection. In this context, government spending can play a risk-reducing role. Other theories, by contrast, predict a race to the bottom, that is, a negative effect. Since international capital mobility may lower taxation, this puts social spending under downward pressure (Mishra 1999). There are also theories saying that globalization has no effect on social spending, and that it is domestic political and economic factors what explains variations in social spending (Bradly et al. 2005).

If we look at historical studies, we can also find examples connecting globalization and social policy in opposite directions. Belgian workers, for example, supported free trade in exchange for social legislation before 1914 (Huberman 2008). A similar story we find in Denmark, where social policy developed in a context of high trade openness (Baldwin 1990). In Germany, by contrast, Bismarckian social policy came along with trade protectionism (Rimlinger 1971); and French employers argued in the late 1920 s that without tariff protection the cost of social insurance would lead to dramatic export losses (Dutton 2002).

The objective of this paper is to contribute to this debate by analyzing the impact of trade openness on the evolution of Spanish social spending between 1850 and 2000. Spain is an interesting case in this sense. It experienced major changes in its trade orientation, combining periods of intense trade protectionism with periods of high trade openness. Interestingly, the historical evidence on the evolution of the Spanish welfare state seems to show the same puzzle that we see in international studies. In the last decades on the $20^{\text {th }}$ century, particularly since the arrival of democracy in the late 1970s, social spending increased along with trade openness. However, in the early stages of modern social policy, in the late 19th century and early 2oth century, Spanish social spending increased gradually in a context of increasing trade protectionism. What can explain this apparent paradox?

I argue in this paper that the impact of trade globalization on social spending is circumstantial. It does not lead to an "automatic" race to the bottom or an "automatic" compensation effect, but it is conditioned by fiscal capacity. Above a minimum level of fiscal capacity, globalization has a positive effect on social spending and the government is able to compensate the population for the costs of globalization. However, below this minimum level of fiscal capacity, the relationship between globalization and social spending is negative, and the government is unable to compensate for globalization costs.

The results of the econometric analysis seem to confirm this 1850-2000 Spain. From the 1960s onwards, trade openness had a positive effect on social spending. However, before that date, it seems that Spanish fiscal capacity was not high enough and trade openness had a negative effect on social spending. This means that both the compensation hypothesis and the race-tothe-bottom hypothesis find some empirical support, but the final outcome depends on fiscal 
capacity. When fiscal capacity is high the compensation effect is confirmed. However, when fiscal capacity is low then the race to the bottom seems to prevail.

The paper is organized as follows. The next section summarizes the main theories and historical studies on the relationship between social policy and globalization. Section 3 describes the evolution of social spending and trade openness in Spain between 1850 and 2000. Section 4 carries out the empirical analysis and discusses the results. Section 5 is devoted to robustness checks and section 6 concludes.

\section{Theoretical and historical background}

In the academic debate there are two main views on the effects of globalization on social spending. According to the race to the bottom or efficiency hypothesis, globalization is expected to have a negative impact on social spending. The reason is that international capital mobility fosters tax competition between governments, which translates into lower public revenue and, therefore, lower social spending. At the same time exposure to international trade compels governments to reduce taxation to promote domestic firms' international competitiveness (Mishra 1999, Garret 2001, Liberati 2007). The second view is the so-called compensation hypothesis. Cameron (1978) was probably the first to observe that trade openness and government size were positively correlated in OECD countries. This was later formalized by Rodrik (1998), who suggests that globalization might have a positive effect on social transfers. The reason is that the increased economic instability associated to international trade exposure generates higher demands for social protection. Rodrik himself, however, warns that globalization (and especially international capital mobility) may also reduce fiscal capacity; so that international trade exposure only leads to higher social spending when the compensation effect dominates.

Alesina and Wacziarg (1998) also found a positive correlation between trade openness and government size, but (instead of the demand-for-compensation mechanism) stressed the role of country size as a mediating factor. According to them, small countries tend to have bigger governments and be more open to trade. Similarly, Epifani and Gancia (2009) found that trade openness correlates positively with government consumption expenditure (although they found no connection with social transfers). As an alternative to Rodrik's demand-for-insurance argument, they hold that more open economies tend to have bigger governments (only) if they export differentiated goods (that is, if their elasticity of substitution between domestic and foreign goods is low). In this case, open economies can benefit from a terms-of-trade externality that shifts part of the cost of taxation abroad. In turn, Chuaire et al. (2017) argue that the correlation between economic openness and government size is conditional on state capabilities. In particular, countries with stronger state capacity have at their disposal a wider menu of policies to overcome the challenges imposed by economic openness. As a result, they might be able to cope with the extra volatility induced by international trade without necessarily increasing public spending.

Other authors, however, have tried to identify the specific conditions under which the demand-for-compensation hypothesis may hold. Adserà and Boix (2002), for example, 
emphasize the role of democracy as a crucial factor in explaining the positive correlation between trade openness and social spending. In democratic regimes, politicians may follow two alternatives. They can choose between trade protectionist policies or they can implement free trade policies complemented with social compensation policies. In authoritarian regimes, however, free trade may be imposed without compensating the losers of trade openness (as these can be excluded from the political process). Similarly, Nooruddin and Simmons (2009) found, for a sample of developing countries, that the positive correlation between openness and social spending depends on the regime type. Only in democratic regimes social spending and trade openness are positively correlated. Analyzing the case of Spain in 1960-2000, Sáenz et al. (2013) also found evidence that democracy reinforced the causal relation from increased openness to greater public expenditure.

From a slightly different angle, Mares (2005) maintains that the positive association between trade openness and welfare state expansion depends on the capabilities of the state to enforce the law. In Mares's model, workers in high-risk sectors (facing high income volatility due to international trade exposure) will support social insurance programs with costs shared across occupations. Workers in low-risk sectors, by contrast, will oppose these programs. The final outcome will depend on the balance of power between these two sectors. However, state capacity will also play a role. In the presence of weak, ineffective states, unable to collect social insurance contributions from sectors that are net contributors to the system, redistribution promises will not be credible and workers in the high-risk sector will find redistributive social policies unattractive.

In historical studies there is also mixed evidence on the relationship between globalization and the welfare state. Huberman and Lewchuk (2003), for example, found that, in Europe, before World War I, social insurance programs were more extensive in more open economies (whereas countries less exposed to international trade opted for alternative mechanisms of social protection based on labor market regulation). In line with Rodrik, Huberman and Lewchuk (2003) suggest that increasing volatility associated to globalization led to bigger demands for social protection, which were more easily meet in democratic countries with proportional representation. Huberman and Meissner (2010), in turn, propose an alternative explanation for the potential positive link between globalization and labor regulation. Especially within European countries, where intra-industry trade was important, pressure from trading partners to emulate labor standards was a key factor in the expansion of labor regulation in parallel to trade openness growth. By contrast, in the New World, where the export of differentiated goods predominated, this pressure was insignificant.

Several individual, country histories seem to confirm this positive link between globalization and social policy. Belgian social legislation before 1914 developed in parallel to the first wave of globalization. The Belgian labor party backed free trade in exchange of social policy expansion and tax reform -to compensate for reduced tariff revenues and finance the new social programs- (Huberman 2008). A similar story is found in Denmark, where early social programs developed in a context of high trade openness. Specially, export-oriented Danish farmers played a crucial role in shaping the 1891 old-age pension scheme. They favored a taxfunded instead of a contributory program (funded from compulsory contributions from 
employers and employees) to avoid the increased labor costs this involved (Baldwin 1990). ${ }^{1}$ In Germany, by contrast, Bismarckian social policy came along with trade protectionism (Rimlinger 1971), suggesting that there is not a clear link between trade openness and social policy expansion. Similarly, in the early debates on the development of social insurance in France, French employers argued that without tariff protection the cost of social insurance would lead to dramatic export losses (Dutton 2002), echoing today's arguments of the efficiency hypothesis.

Meanwhile, Haggard and Kaufman (2008) consider that globalization effects on social spending are more ambiguous. According to them, the main difference between protectionist and open economies are not related to the level of social spending but to the way social protection is funded. Protectionist countries (like Latin American countries during the 1960-1970s) tended to create contributory social security systems. These implied higher labor costs, but domestic companies (protected from international competition) could easily transfer social security costs to final prices and consumers. By contrast, more open economies (more concerned about increasing labor costs) were less prone to accept contributory systems and more willing to accept tax-funded programs (which impose the burden of social protection to the general public).

Queralt (2017), in turn, has proposed an alternative way by which trade protectionism may affect public finances. According to him, fiscally weak states may try to achieve higher tax compliance by granting trade protection to (noncompetitive) domestic producers (which, now, would be willing to pay more taxes in exchange of protection). This, in turn, would allow the government to finance levels of public spending otherwise unfeasible. Interestingly, Queralt (2017) argues that this "protection for tax compliance" could be qualified as a second-best solution for weak states, in line with Rodrik (2008)'s view on second-best institutions. The idea is that inefficiencies associated to trade protectionism may end up having a global positive balance if it generates "enough tax revenue to finance public spending in the absence of sufficient bureaucratic means" (p. 640).

\section{Trade openness and social spending in Spain}

Spanish trade policy has experienced dramatic changes over the last century and a half. Figure 1 shows the evolution of trade openness (measured as the sum of imports plus exports divided by the GDP) in Spain between 1850 and 2000. As can be seen, trade openness increased gradually since 1850 , due to a considerable reduction in international transport costs (Federico and Tena-Junguito 2017) and the gradual reduction in tariff protection. This liberalization process began to be questioned in 1875 , when the government amended the Figuerola tariff of 1869 . But still in the 1880 s Spain signed various trade agreements with its main trading partners. The protectionist turn was definitively consolidated with the Cánovas tariff, in 1891. Later, the 1906 Salvador tariff and the 1922 Cambó tariff consolidated this protectionist trend, leading to an inward-looking development strategy that was promoted by the successive

\footnotetext{
${ }^{1}$ To finance the new Danish old-age pension system, a beer tax was created, initiating a long-lasting Scandinavian tradition in which indirect taxes have had an important role in the funding of social policy (see Baldwin 1990).
} 
Spanish governments. As a result, the degree of trade openness in Spain decreased gradually since the late 19th century (Tena 1999, Tirado 1996).

However, the lower levels of trade openness are observed after the Spanish civil war (193639 ), in the 1940s and 1950s, during the so-called autarkic period (figure 1). This is partly the result of the collapse of international trade after the Great Depression and the effects of the Spanish civil war, but it is also the result of an intentional government policy. After the war, the Franco dictatorship pursued an import substitution industrialization strategy, based on strict controls on international trade and international capital movements. A very active state intervention policy was also applied in domestic economic affairs. This extreme policy, however, was gradually abandoned throughout the 1950s, and especially after 1959. In 195759 an economic crisis originated in the external sector occurred. The lack of dynamism of the Spanish exports plus a big overvaluation of the Spanish peseta led to a big deficit in the commercial balance. To correct this, the government devised the so-called 1959 Stabilization Plan. The peseta was devaluated to gain international competitiveness and a strict monetary policy was implemented to defend the new exchange rate. In parallel, a number of liberalizing measures were introduced and most aggressive forms of state intervention were abandoned. State controls over private investment (including foreign direct investment) diminished, and the economy became gradually more open to international trade (Prados de la Escosura et al. 2012, Carreras and Tafunell 2018). This process continued and consolidated with the advent of democracy in 1977 and the degree of trade openness of the Spanish economy increased steadily until 2000 (figure 1 ).

Figure 1. Trade openness (in logs) in Spain, 1850-2000

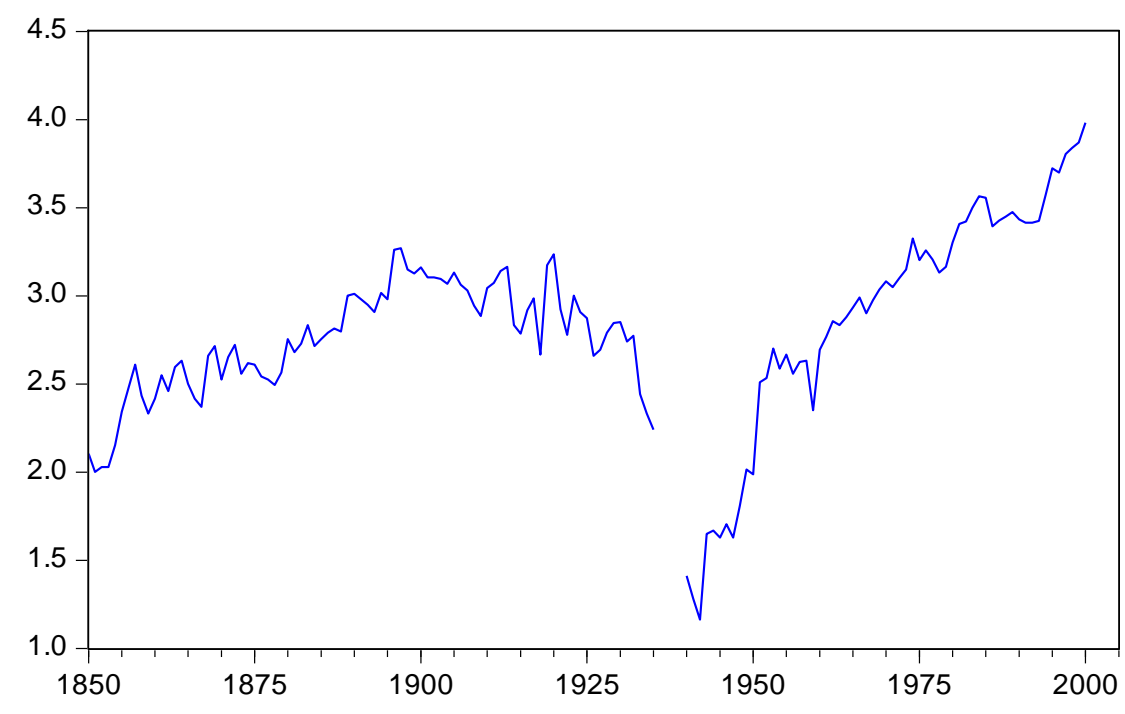

Source: Tena (2005).

As for the evolution of social spending, the Spanish case shows changing patterns too (figure 2). The origins of Spanish modern social policy can be traced back until at least 1883, when the government created the Commission for Social Reform (Comisión de Reformas Sociales). The 
objective of the Commission was to propose solutions to improve the living conditions of the working class, but its activities hardly translated into specific measures until 1900, when the government passed the law on workers' compensation, providing benefits to industrial workers injured in the workplace. The impact of this measure, however, was very limited. Legal benefits were very low and companies often failed to fulfil their commitments because of the lack of inspection (Silvestre and Pons 2010). Shortly afterwards, in 1908, the government introduced a voluntary, state-subsidized old-age insurance scheme. But, again, this program had a very limited impact. In 1918, barely $1 \%$ of the workforce was covered, largely due to scarce public funding (Elu 2010). None of these measures resulted in a significant increase in social spending, which continued to be dominated by traditional poor relief and remained stagnant with fluctuations between 1850 and 1918 (figure 2).

Figure 2. Spanish public social spending (\% of GDP), 1850-2000

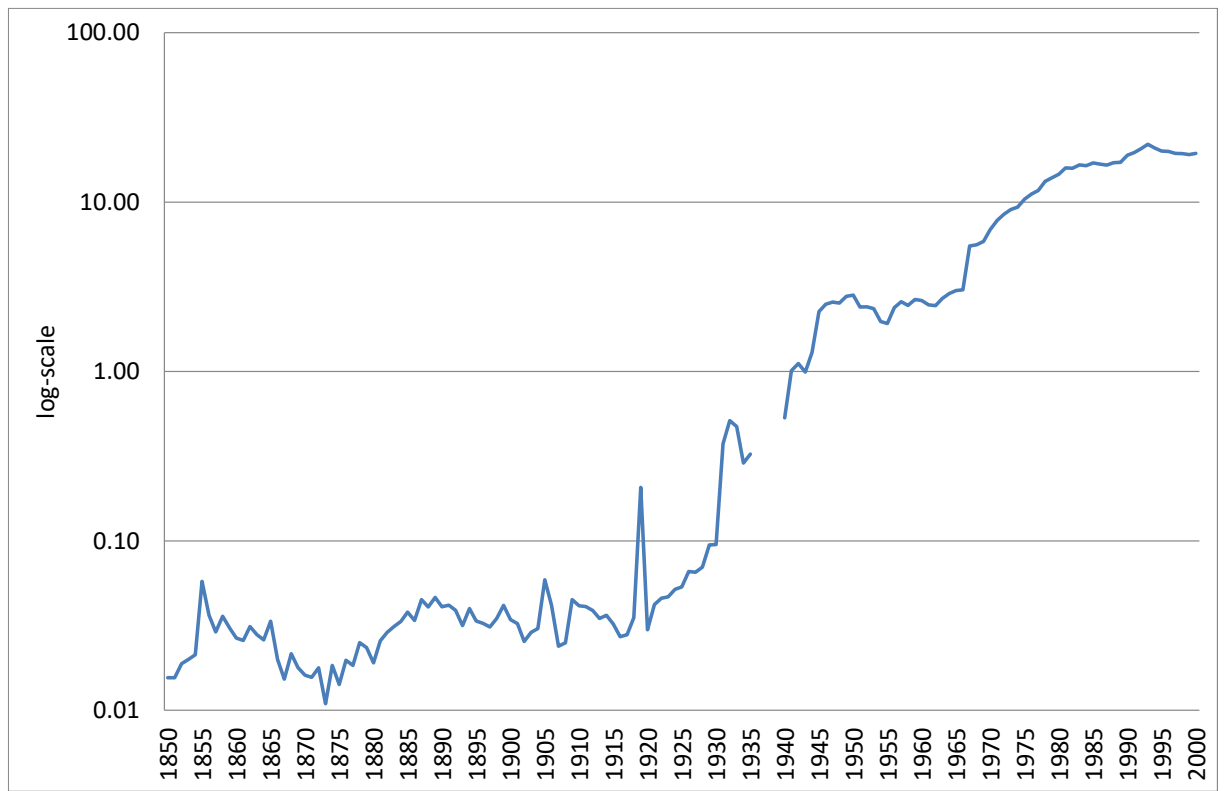

Source: Espuelas (2013). Note: The data fits the definitions of social spending by the OECD and includes social spending by the Spanish central government, the autonomous communities, and Social Security institutions. Local social spending has not been included for two reasons. First, the development of social spending in Spain was the sole responsibility of the central government and the autonomous communities that absorbed part of its competences after the restoration of democracy in 1977. Second, the series offered by Espuelas (2013) on local social spending has many gaps, entailing an unnecessary loss of information for the econometric analysis (less than 90 observations are available). Following Lindert (2004), civil servants' pensions have also been excluded because they do not represent benefits for the general population, but are rather the result of the particular employment relation between the state and its employees.

This began to change in the turbulent years after World War I, when the government established a compulsory old-age pension scheme (replacing the former old-age voluntary scheme); and the introduction of various new programs (such as maternity insurance, unemployment insurance or the extension of workers' compensation to rural workers) was discussed. However, none of these programs were eventually passed before the Primo de Rivera dictatorship (1923-30). In 1931, with the democratic advance of the Second Republic 
(1931-36), social policy regained momentum and the social programs that had already been discussed in the early 1920 s were introduced. Thus, maternity leave was declared mandatory; a voluntary, state-subsidized unemployment insurance scheme was established; and workers' compensation was extended to rural workers. The government also tried to create a new health insurance (providing sickness leave and health-care), which was to be integrated together with existing programs into a single, unified social security system. However, political discussion over this plan dragged on for years, so that it could not finally be passed before the 1936 military coup (Samaniego 1988). As a result, social spending began to grow after 1919, but even in 1935 it was still below 1\% of GDP (figure 2).

The development of social policy in Spain throughout this period was, in fact, slower than in most European countries (Lindert 2004). Late economic development, low population ageing, and difficulties to consolidate democracy are probably the most important explanatory factors. But there are two additional factors that played a crucial role in Spain: weak fiscal capacity and continued business opposition to social insurance.

Public deficits were constant in the early decades of the $20^{\text {th }}$ century. The government unsuccessfully tried to reform the tax system on various occasions since 1909. Among these projects, the one presented by Santiago Alba in 1916 to create a tax on extraordinary business profits, or the attempts to create a sales tax in 1918 and 1919, and an income tax in 1920, 1921, and 1922 stand out. None of these projects were passed. Even when the income tax was finally established in 1932, it was a very moderate reform, with low collection capacity (Comín 1996). Faced with this lack of fiscal capacity, the Spanish government was reluctant to assume the cost of new social programs. That is why the government initially advocated for voluntary schemes, and then, when social demands increased (after World War I and during the II Republic), opted for compulsory schemes, which were financed by employers' and employees' contributions with little public subsidy. This, however, generated strong business opposition, especially from rural owners and small and medium-sized businesses. These groups opposition to social insurance was, indeed, common also in other European countries (Mares 2003). However, unlike countries like Germany, for example, where big companies were of greatest importance, in Spain, small and medium-sized companies were predominant; making the problem of business opposition more acute.

After the Spanish Civil War (1936-39), Franco's dictatorship (1939-76/77) established a conservative social insurance model. The social insurance schemes introduced before the civil war continued in operation, with the only exception on unemployment insurance, which was abolished and not reintroduced until 1961. But some new programs were also launched. In 1938, for example, the government introduced a family allowances program (Subsidio familiar), providing bonus payment to all wage earners depending on the number of children. And, in 1942-44, a compulsory health insurance scheme was also established. However, social insurance coverage was largely limited to low- and medium-income industrial workers'; and social benefits were low (Pons and Vilar 2014). As a result, social spending remained low and stagnant around 3\% of GDP, between 1945 and 1965 (figure 2).

\footnotetext{
2 Rural laborers were excluded from old-age pensions before 1943. Permanent rural laborers were excluded from health insurance until 1953, and non-permanent rural laborers until 1958.
} 
Moreover, this meager social safety net was almost exclusively financed by employers' and employees' compulsory contributions. The government contributed to social insurance with very little public subsidy. This allowed Franco dictatorship to finance its meager social policy without increasing taxation, and this time it seems that employers showed little opposition to social insurance. The strong repression of the labor movement along with trade protectionism allowed companies to easily transfer the cost of social insurance to wages and final prices (Espuelas 2012). This, however, started changing in the mid-1960s. After the liberalizing measures introduced in parallel with the 1959 Stabilization Plan, the Spanish economy initiated a period of rapid economic growth, which in turn led to increasing demands for social protection. Moreover, a clandestine labor movement expanded during the 1960s. The Collective Bargaining Act (into effect since 1961) allowed employees to negotiate their working conditions with employers. Strikes remained illegal, but after 1963 they became a common instrument in collective bargaining, and organized labor took advantage of the new legislation to expand (Molinero and Ysas 1998). This, along with university student opposition movements plus the rise of social catholic groups supporting labor demands, became the main source of political instability faced by Franco dictatorship in the 1970s (Tusell 2005).

In response to this new political context, a new Social Insurance Act was passed in 1963 (coming into effect in 1967). Preexisting social insurance schemes were unified within a single social security system, and coverage was extended to all wage-earners (albeit the population without stable ties to the labor market remained unprotected). As a result, social spending started to grow rapidly after 1967 (figure 2). Since the funding of social security relied on employers' and employees' compulsory contributions, increasing social spending translated into increasing labor costs for Spanish companies. However, increased workers' bargaining power and growing exposure to international competition prevented Spanish companies to transfer the cost of social insurance to wages and final prices as easily as before. In the 1970s employers' complaints about compulsory contributions became a commonplace (Espuelas 2012).

This gradually changed with the restoration of democracy in 1977 and the tax reform that came with it. Income tax was introduced in 1978 and a new VAT (replacing the former transactions and luxury taxes) was established in 1986 (Torregrosa-Hetaland 2015). This allowed for a continued expansion of social spending. Health care became universal in 1986, old-age and disability non-contributory pensions were introduced in 1990; and minimum income programs were gradually introduced by regional governments also in the 1990s. As a result, social spending continued to grow after the arrival of democracy until it stabilized during the 1980 s and especially after 1993 (figure 2).

From the Spanish historical experience, it is hard to find a clear link between trade globalization and social spending. Before the Spanish civil war (especially after World War I), social spending grew (albeit with difficulties) in a context of increasing trade protectionism. During this time period, there were no attempts to reach agreements such as those implemented in Denmark or Belgium to develop tax-funded social programs in exchange for support for trade liberalism. After the 1891 protectionist turn, the inward-looking development strategy was not questioned at any time by successive governments (and the persistent unwillingness of the government to increase taxation must have made this type of 
agreements unappealing). Before 1913, the government response to compensate workers for the $19^{\text {th }}$ century "grain invasion" was limited to trade protectionism (Betrán and Pons 2011). And, as already mentioned, after World War I, social spending increased gradually but in a context of increasing trade protectionism.

After the Spanish civil war, trade protectionism (plus the repression of the labor movement) reduced the customary employers' opposition to social insurance. To some extent this resembles the argument "protection for tax compliance" developed by Queralt (2017). However, as mentioned before, once a very basic social safety net was established by 1945 , social spending remained stagnant until the mid-1960s (in a context of high trade protectionism); and after 1967, social spending grew in a context of increasing trade openness (both during the last years of the dictatorship and in today's democracy), suggesting that trade openness and social spending could be positively correlated.

In this sense, it is interesting to note the change in attitude of employers towards social policy in this later period. In official documents from 1980 and 1982 on the situation of Spanish social security, the Spanish employer association CEOE (Spanish Confederation of Business Organizations) said that: "it seems convenient that social security continues its extension until it covers the entire population (...), but we do not agree that such extension should be done at the expense of companies" (p.29). The reason, they argued, is that high social contributions "discourage job creation" and "represent a real obstacle for our sales abroad, compared to countries whose social security is financed to a great extent or to a much greater extent by fiscal resources [direct or indirect taxes]" (p. 45). Indeed, after the arrival of democracy in 1977 and the subsequent tax reform, government subsidies to the social security system increased and compulsory social contributions paid by employers and employees gradually lost ground.

In other words, the funding of social insurance adapted to become more compatible with international trade. My hypothesis is that one of the factors that explain why this time it was possible to find the way to expand social spending in a context of increasing trade openness is because fiscal capacity was greater than in the past.

\section{Empirical analysis}

\section{Hypothesis and data}

Partly building on Mares (2005), I hypothesize that the effect of globalization on social spending is conditional on the government fiscal capacity. The idea behind this that, even if there are demands for compensation due to higher exposure to international trade, governments will only be able to meet these demands if they have enough fiscal resources. The idea that fiscal capacity can play a role in the relationship between social spending and trade openness is not new. As mentioned before, Rodrik himself warned that globalization (and especially international capital mobility) may diminish governments' fiscal capacity; so that international trade exposure will only lead to higher social spending when the compensation effect dominates. In the efficiency hypothesis it is also assumed that globalization reduces fiscal capacity. Here, I relax this assumption. Globalization may reduce 
fiscal capacity but not necessarily. In some countries fiscal capacity can be already weak ex ante (that is, before a potential increase in trade openness occurs). In other countries, by contrast, fiscal capacity can remain high after trade openness increases. For example, open economies may choose a mix of taxes (for example, relying more heavily on consumer taxes) more compatible with international economic integration (see Lindert 2004). Similarly, Haggard and Kaufman (2008) show that export-oriented countries are more likely to adopt taxfunded social insurance system, instead of compulsory contributions-based systems that involve higher labor costs.

From this perspective, trade openness will only have a positive effect on social spending when fiscal capacity is high. When fiscal capacity is low the effect of trade openness will be negative. In this later case governments could arguably increase social spending by increasing trade protectionism and reducing trade exposure. As seen before, this can be particularly the case if, as suggested by Queralt (2017), fiscally weak states may try to obtain higher tax compliance by granting trade protection to domestic producers.

To test the relationship between trade openness and social spending, I have estimated the following equation:

$$
\text { SocSp }=\alpha_{0}+\beta_{1} \text { TradeOp }+\beta_{2} \text { Interaction }+\beta_{3} \text { FisCap }+\beta_{4} Z+\varepsilon_{1}(1)
$$

where SocSp is public social spending (as a \% of GDP); TradeOp is the degree of trade openness, FisCap is a measure of fiscal capacity, Interaction is the interaction term between trade openness and fiscal capacity, and $Z$ stands for a set of control variables. Since the objective of this paper is to test whether the impact of trade openness is conditional on fiscal capacity, the variable of interest is the interaction term. The data on social spending are those shown in figure 2, coming from Espuelas (2013). ${ }^{3}$ Trade openness is measured as the sum of imports plus exports divided by GDP. The figures are those in figure 1, coming from Tena (2005).

As a measure of fiscal capacity, I use the ratio of the central government's tax revenues to the public debt in circulation (also of the central government). This ratio aims at capturing the ability of the government to raise public revenues as it assumes new functions. If the ratio is low (that is, if tax revenues are small in relation to the public debt in circulation) this means that the government is unable to raise enough taxes to meet its obligations (and needs to rely on external funding). By contrast, the larger this quotient is (the bigger tax revenues in relation to public debt), the greater the state's fiscal capacity is assumed to be. The data come from Comín and Díaz (2005). This measure is preferred to alternative measures of fiscal capacity (like taxation as a share of GDP). Since it puts taxation revenue in relation to public debt, it gives us an indication of fiscal capacity no matter the size of the public sector. By contrast, if we use taxation as a share of GDP, we could find that a small government (whose tax revenue is $10 \%$ of GDP), for example, can have sound public finances; while a bigger government (collecting, for example, 20\% of GDP) could be more in debt (which means that this situation would probably be unsustainable in the medium- or long-run and that this government would

\footnotetext{
${ }^{3}$ The years of the Spanish civil war, 1936-39, have not been included in the analysis because of the lack of data.
} 
be unable to assume new costs -like new social programs-). Nevertheless, in later sections, I show that the results are robust to the use of alternative measures of fiscal capacity.

The control variables include a group of variables common in quantitative studies on the determinants of social spending. Specifically, I have included the GDP per capita, the percentage of population over 65 years old, and the level of inequality. GDP per capita figures come from Prados de la Escosura (2003). The data on the population over 65 years old come from Nicolau (2005); and inequality figures correspond to the Gini index devised by Prados de la Escosura (2008). Since the role of democracy has been often emphasized in empirical studies on the determinants of social spending (Lindert 2004), one additional obvious control is the political regime. Moreover, as mentioned before, there are theories noting that the positive correlation between social spending and trade openness predicted by the compensation hypothesis depends on the existence of democracy. To capture the potential effect of the political regime I have included three dummy variables, which take value one in the years of universal male suffrage (1868-77; 1890-1922), democracy (1931-36; 1977-2000) and dictatorship (1923-30; 1939-76), and value zero otherwise. This means that the years of census suffrage or elite democracy have been used as a baseline. ${ }^{4}$ Finally, I have also included the share of seats of left-wing parties in the years of universal male suffrage and democracy (Hicks 1999); and the number of government changes in the years of dictatorship to capture the potential positive effect of political instability (Cutler and Johnson 2004). The data come from Linz et al. (2005) and Urquijo (2001), respectively. All the variables in the analysis are in logarithms to derive elasticities.

\section{Results and discussion}

Since the analysis involves time series, I have first checked whether the series are stationary or not. I applied both the augmented Dickey-Fuller test and the Phillips-Perron test to the series included in the model. The results are shown in table 1, and indicate that all of them are integrated series of order one, I (1). Next, I have tested whether the series are cointegrated. I applied the Engle-Granger cointegration test to the residuals of the OLS estimation in column 3 , table 3. The results confirm that the series are cointegrated (see table 2). When the series are cointegrated, the OLS estimator is consistent, but it presents problems of asymptotic bias and is not an efficient estimator. Therefore, in addition to the Least Squares estimation, I have also reported the results from the Fully Modified Least Squares (FMOLS) estimation. FMOLS use a semi-parametric correction of the least-squares estimator to deal with the potential problems arising from the existence of a cointegrating relation, and is asymptotically efficient (Phillips and Hansen 1990).

\footnotetext{
${ }^{4}$ Following Espuelas (2017), I have classified Spain as a democracy from Boix et al. (2012). In the remaining years, Spain has been classified as a dictatorship when the variable xconst of Marshall and Jaggers (2010) takes value 1 (that is, when the executive has unlimited authority), and as universal male suffrage when the right to vote formally existed but Boix et al. (2012) do not consider it as a fully democratic period.
} 


\begin{tabular}{|c|c|c|c|c|}
\hline & \multicolumn{2}{|c|}{ Test specification: constant } & \multicolumn{2}{|c|}{ Test specification: trend and constant } \\
\hline & $\begin{array}{l}\text { Augmented } \\
\text { Dickey-Fuller }\end{array}$ & Phillips-Perron & $\begin{array}{l}\text { Augmented } \\
\text { Dickey-Fuller }\end{array}$ & Phillips-Perron \\
\hline & $\mathrm{t}$-Statistic & t-Statistic & $\mathrm{t}$-Statistic & t-Statistic \\
\hline \multicolumn{5}{|l|}{ In levels: } \\
\hline Log(social spending) & -0.060 & 0.050 & -1.849 & -2.039 \\
\hline Log(GDP per capita) & 1.706 & 2.076 & -0.467 & -0.269 \\
\hline Log(population 65) & 3.711 & 3.278 & 0.164 & -0.259 \\
\hline $\log ($ Gini) & -2.545 & -2.446 & -2.535 & -2.437 \\
\hline Log(openness) & -2.108 & -2.049 & -2.694 & -2.600 \\
\hline Log(fiscal revenues/public debt) & -0.840 & -0.743 & -1.761 & -1.580 \\
\hline \multicolumn{5}{|l|}{ In differences: } \\
\hline Log(social spending) & $-16.243^{* * *}$ & $-17.229 * * *$ & $-16.217^{* * *}$ & $-17.362 * * *$ \\
\hline Log(GDP per capita) & $-9.589 * * *$ & $-9.589 * * *$ & $-9.920^{* * *}$ & $-9.896 * * *$ \\
\hline Log(population 65) & $-14.610^{* * *}$ & $-14.558^{* * *}$ & $-15.728 * * *$ & $-15.238^{* * *}$ \\
\hline $\log ($ Gini) & $-14.349 * * *$ & $-14.438^{* * *}$ & $-14.302 * * *$ & $-14.392 * * *$ \\
\hline Log(openness) & $-10.241 * * *$ & $-13.403^{* * *}$ & $-10.265^{* * *}$ & $-13.397^{* * *}$ \\
\hline Log(fiscal revenues/public debt) & $-8.823 * * *$ & $-8.851 * * *$ & $-8.794^{* * *}$ & $-8.823 * * *$ \\
\hline
\end{tabular}

Null hypothesis: the variable has a unit root, * rejection at $10 \%, * *$ rejection at $5 \%, * * *$ rejection at $1 \%$.

Table 2. Engel-Granger cointegration test on residuals

\begin{tabular}{lccc}
\hline \hline Model specification & t-statistic & \multicolumn{2}{c}{$p$-value } \\
& & \\
none & -6.816 & 0.008 \\
constant & -7.039 & 0.009 \\
trend and constant & -7.046 & 0.016 \\
\hline \hline
\end{tabular}

Note: test from the regression in table 3 , column 3.

Null hypothesis: series are not cointegrated.

The results of the regression analysis are shown in table 3 (OLS results in columns 1 to 3 , and FMOLS results in columns 4 to 6 ). In columns 1 and 4 , I report univariate regressions of social spending on trade openness, which initially show a negative coefficient. However, when fiscal capacity and the interaction term between fiscal capacity and trade openness are added to the regression (columns 2 and 5 ) the coefficient associated to trade openness turns positive. More interestingly, the coefficient associated to the interaction term between trade openness and fiscal capacity is positive and highly statistically significant. This result holds for both the OLS and the FMOLS regressions. In columns 3 and 6, control variables are included. The size of the coefficient of the interaction term decreases, indicating that it was at least partially capturing the effect of some of these variables, but it remains positive and significant. This suggests that the effect of trade openness on social spending is conditional on fiscal capacity. Greater fiscal capacity involves a greater positive effect of trade openness on social spending. Again, this result holds for both the OLS and the FMOLS regressions. 
Table 3. Trade openness and social spending in Spain, 1850-2000

Dependent Variable: Log(social spending as a \% of GDP)

OLS

OLS

FMOLS

FMOLS

FMOLS

(1)

(2)

(3)

(4)

(5)

(6)

Log(Openness)

$-0.510 *$

$-0.104$

$-0.507$

$0.299-0.012$

$\log ($ Openness $) * \log ($ Fiscal Capacity)

(0.166)

(0.378)

(0.322)

(0.270)

Log(Fiscal Capacity)

$0.825^{* * *} \quad 0.387$

$0.891 * * * \quad 0.571$

(0.135) (0.219)

(0.221) (0.289)

$-1.461 * * * \quad-0.633$

$-1.622 * * \quad-1.209$

(0.449) (0.648)

(0.734)

(0.851)

C

\begin{tabular}{|c|c|c|c|c|c|c|c|c|c|c|}
\hline-4.172 & $* * *$ & -3.923 & $* * *$ & 8.523 & $* *$ & -4.206 & $* * *$ & -3.867 & $* * *$ & 7.221 \\
\hline (0.407) & & $(0.676)$ & & (3.719) & & (0.837) & & $(1.087)$ & & (4.855) \\
\hline 0.059 & $* * *$ & 0.037 & $* * *$ & 0.007 & & 0.058 & $* * *$ & 0.036 & $* * *$ & 0.016 \\
\hline .002$)$ & & (0.003) & & (0.011) & & $(0.004)$ & & (0.005) & & (0.015) \\
\hline
\end{tabular}

Controls

No

No

Yes

No

No

Yes

Adjusted R-squared

$\begin{array}{rrrrrr}0.892 & 0.952 & 0.975 & 0.892 & 0.952 & 0.975 \\ 0.876 & 0.582 & 0.417 & 0.877 & 0.586 & 0.418 \\ 147 & 147 & 147 & 147 & 147 & 147\end{array}$

S.E. of regression

147

147

147

147

147

Notes: ${ }^{*}$ significant at $10 \%,{ }^{* *}$ significant at $5 \%,{ }^{* * *}$ significant at $1 \%$. Standard errors in parenthesis. Estimation method is Ordinary Least Squares in columns 1 to 3, and Fully Modified Least Squares in columns 4 to 6. Controls include GDP per capita, the share of population over 65 , the Gini coefficient (all variables in logs) and dummies for the political regime. See the text for details. The results associated with the control variables generally point in the expected direction, with population aging and democracy having a positive effect and inequality a negative effect. Here I do not show them for the shake of simplicity, but are available upon request. 
If the effect of trade openness on social spending is conditional on fiscal capacity, then it is worth asking when this effect has exactly been positive in Spain between 1850 and 2000. In other words, when has fiscal capacity been high enough for Rodrik's compensation effect to dominate over the race-to-the-bottom effect? Confronting the actual data on Spain with the coefficients associated to trade openness in table 3, we can calculate the years in which Spanish fiscal capacity has been high enough for globalization effect to be positive. To do so we first need to calculate the marginal effect of trade openness:

$$
\frac{\partial \text { social spending }}{\text { dtrade opennes }}=\beta 1+\beta 2 * \log (\text { Fiscal capacity) (2) }
$$

Then from the marginal effect we can calculate, by solving equation (2), the level of fiscal capacity needed for globalization to have a positive effect:

$$
\log (\text { Fiscal capacity })=-\frac{\beta 1}{\beta 2} \quad \text { (3) }
$$

If we take the coefficients from regression (5) in table 3 the result is that the level of fiscal capacity needed for globalization's effect to be positive is $-0.336(-0.299 / 0.891)$. This means that, according to our regressions, trade globalization in Spain had a positive effect on social spending between 1958 and $1998 .{ }^{5}$ This is illustrated in figure 3, where the log of fiscal capacity is plotted against the log of trade openness.

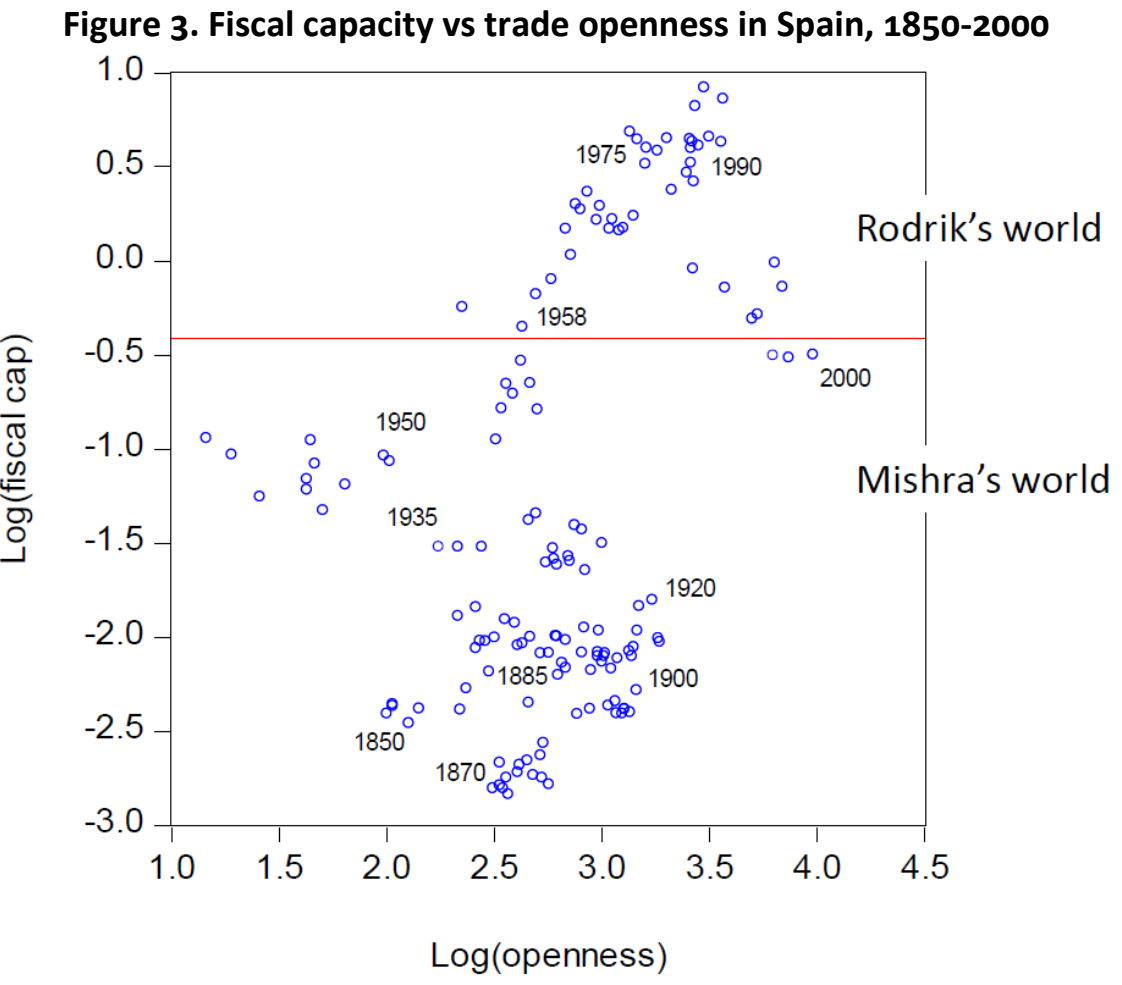

\footnotetext{
5 If we took the coefficients from regression (6) in table 3 (instead of regression 5) the results would be similar [0.021=0.012/0.571], meaning that globalization effect would have been positive between 1962 and 1993 .
} 
Figure 3 shows some interesting patterns. First, fiscal capacity does not seem correlated to trade openness. This means that, as suggested before, globalization (trade openness in our case) does not automatically lead to a race to the bottom or lower taxation. The dots situated in the upper right corner indicate that in certain periods Spain managed to have high fiscal capacity in contexts of high trade openness. The interesting point here is that above the solid line (that is, when fiscal capacity is high enough) Rodrik's compensation effect prevails over the race-to-the-bottom effect. During these years the government had enough fiscal capacity to compensate the population for the costs of globalization; and therefore, trade openness has a positive impact on social spending. These were (according to our regressions) the years after 1958 , when the Spanish economy entered a phase of rapid economic growth as a result of the liberalizing reforms associated with the 1959 Stabilization Plan. As seen in section 3, when the demands for social protection increased from the mid-1960s onwards, government social spending increased in a context of growing trade openness. Subsequently, the fiscal reforms of democracy allowed the process of growth in social spending to continue in a globalized context.

However, below the solid line (that is, when fiscal capacity is not high enough) the race-to-thebottom hypothesis prevails. The government, in this case, did not have enough fiscal resources to compensate the population for the costs of globalization, and trade openness and social spending would have been negatively correlated. This seems to have been the case before the Spanish Civil War and the early decades of Franco dictatorship. As shown in section 3, from the inception of modern social policy in Spain, in the late $19^{\text {th }}$ century and early $20^{\text {th }}$ century, social spending grew (slowly) in a context of increasing trade protectionism. Even during the II Republic (1931-36) social policy expansion took place in a context of strong trade protectionism; and Spanish policy makers resorted to social insurance programs (financed from compulsory contributions from employers and employees) to overcome the inability/unwillingness of the government to increase taxation to finance social policy. This strategy was taken to an extreme during the Franco dictatorship, when social spending became almost exclusively funded from compulsory social contributions, and the customary employers' opposition to compulsory was appeased by intense labor repression and high trade protectionism.

\section{Robustness checks}

One might argue that, in addition to trade openness, the variability of the terms of trade has to be considered in the analysis to have an appropriate measure of the external risk. If the variability of the terms of trade varies considerably over time, then trade openness alone would be a misleading measure of the economic volatility induced by exposure to international markets. In table 4, I control for the potential effect of the variability in the terms of trade. I have included in the regressions the interaction between trade openness and the variability of the terms of trade (measured -as in Rodrik (1998)- as the standard deviation of the first (log) differences in the terms of trade). The data come from Tena (2005). To test whether the impact of greater exposure to external risk is conditional on fiscal capacity, I have also included 
the triple interaction: trade openness*terms-of-trade variability*fiscal capacity. The results are shown in table 4. As before, I report the results of the OLS and FMOLS regressions. The coefficients associated to the variability of the terms of trade and its interactions are not statistically significant; and the coefficients associated to the interaction term between fiscal capacity and trade openness remain statistically significant and of similar size. It seems that, in the Spanish case, the changes in the variability of the terms of trade are not big enough to add anything new to the effect of trade openness already captured in table 3.

Table 4. Controlling for the variability of terms of trade

\begin{tabular}{|c|c|c|c|c|}
\hline \multicolumn{5}{|c|}{ Dep. Variable: Log(social spending as a \% of GDP) } \\
\hline & OLS & & FMOLS & \\
\hline \multirow[t]{2}{*}{ Log(Openness) } & 0.032 & & 0.148 & \\
\hline & (0.409) & & $(0.532)$ & \\
\hline \multirow[t]{2}{*}{ Log(Openness)* Log(Fiscal Capacity) } & 0.467 & $*$ & 0.657 & $* *$ \\
\hline & $(0.238)$ & & $(0.312)$ & \\
\hline \multirow[t]{2}{*}{ Log(Fiscal Capacity) } & -0.837 & & -1.424 & \\
\hline & (0.690) & & $(-0.9)$ & \\
\hline \multirow[t]{2}{*}{ Log(Terms-of-trade variability) } & 0.125 & & 0.141 & \\
\hline & $(0.135)$ & & $(0.176)$ & \\
\hline \multicolumn{5}{|l|}{ Log(Terms-of-trade variability) } \\
\hline \multirow[t]{2}{*}{ *Log(Openness) } & -0.041 & & -0.055 & \\
\hline & $(0.046)$ & & $(0.060)$ & \\
\hline \multicolumn{5}{|l|}{ Log(Terms-of-trade variability) } \\
\hline \multirow[t]{2}{*}{ *Log(Openness)*Log(Fiscal Capacity) } & 0.003 & & -0.002 & \\
\hline & (0.010) & & $(0.013)$ & \\
\hline \multirow[t]{2}{*}{ C } & 9.332 & $* *$ & 8.906 & $*$ \\
\hline & (3.905) & & $(5.061)$ & \\
\hline \multirow[t]{2}{*}{ Trend } & 0.008 & & 0.016 & \\
\hline & $(0.012)$ & & $(0.016)$ & \\
\hline Controls & Yes & & Yes & \\
\hline Adj. R-squared & 0.975 & & 0.975 & \\
\hline S.E. of regression & 0.420 & & 0.422 & \\
\hline Obs. & 147 & & 147 & \\
\hline
\end{tabular}

Notes: ${ }^{*}$ significant at $10 \%, * *$ significant at $5 \%, * * *$ significant at $1 \%$. Standard errors in parenthesis. Control variables are the same as in table 3 .

I have also checked whether my results are robust to the use of alternative indicators of fiscal capacity. In the baseline estimations I used the ratio of the central government's tax revenues to the public debt in circulation as a measure of fiscal capacity. Alternative measures, such as taxation as a share of GDP, were in principle expect to be automatically related to social spending as share of GDP. Here, I have replicated my baseline results but using the following 
measures of fiscal capacity: 1) central government tax revenues as a share of GDP6; 2) the inverse of the ratio of interest on public debt to government tax revenue, that is: [1-(interest on public debt/gov. tax revenue)], to capture the share of tax revenues not devoted to satisfy the payment of interest on public debt. The data come from Comín and Díaz (2005). The results are shown in table 5 , and as before, I report the results from both the OLS and the FMOLS estimations. In all regressions, columns 1 to 4 , the coefficient associated to the interaction term between trade openness and our two alternative measures of fiscal capacity have a positive sign and are statistically significant. The results, therefore, point in the same direction as those of section 4, confirming that globalization effect on social spending is conditional on fiscal capacity.

Table 5. Alternative measures of fiscal capacity

\begin{tabular}{|c|c|c|c|c|c|c|c|c|}
\hline \multicolumn{9}{|c|}{ Dependent Variable: Log(social spending as a \% of GDP) } \\
\hline & OLS & & FMOLS & & OLS & & FMOLS & \\
\hline \multirow[t]{2}{*}{ Log(Openness) } & -1.819 & $* * *$ & -2.536 & $* * *$ & 0.250 & & 0.157 & \\
\hline & $(0.647)$ & & $(0.820)$ & & $(0.292)$ & & $(0.377)$ & \\
\hline \multicolumn{9}{|c|}{ Log(Openness)* Log(Tax revenue over } \\
\hline \multirow[t]{2}{*}{ GDP) } & 0.490 & $*$ & 0.721 & $* *$ & & & & \\
\hline & $(0.268)$ & & $(0.339)$ & & & & & \\
\hline \multirow[t]{2}{*}{ Log(Tax revenue over GDP) } & -2.369 & $* *$ & -3.176 & $* * *$ & & & & \\
\hline & $(0.941)$ & & $(1.192)$ & & & & & \\
\hline \multirow[t]{2}{*}{$\begin{array}{l}\text { Log(Openness) } * \log (\text { Ratio interest } \\
\text { public debt) }\end{array}$} & & & & & 3.335 & $* * *$ & 3.807 & $* * *$ \\
\hline & & & & & $(1.082)$ & & $(1.383)$ & \\
\hline \multirow[t]{2}{*}{ Log(Ratio interest on public debt) } & & & & & -7.613 & $* * *$ & -8.790 & $* *$ \\
\hline & & & & & $(2.864)$ & & (3.663) & \\
\hline \multirow[t]{2}{*}{$\mathrm{C}$} & 7.502 & $*$ & 8.392 & & 10.254 & $* * *$ & 9.397 & $* *$ \\
\hline & $(4.355)$ & & $(5.534)$ & & $(3.593)$ & & $(4.597)$ & \\
\hline \multirow[t]{2}{*}{ Trend } & 0.018 & & 0.029 & $*$ & 0.007 & & 0.010 & \\
\hline & $(0.011)$ & & $(0.015)$ & & $(0.010)$ & & $(0.013)$ & \\
\hline Controls & Yes & & Yes & & Yes & & Yes & \\
\hline Adjusted R-squared & 0.974 & & 0.974 & & 0.975 & & 0.975 & \\
\hline S.E. of regression & 0.426 & & 0.429 & & 0.417 & & 0.420 & \\
\hline Obs. & 147 & & 147 & & 147 & & 147 & \\
\hline
\end{tabular}

Finally, table 6 shows the results of a placebo test. I have switched the dependent variable of my analysis. Instead of using the log of social spending as a \% of GDP I have used the log of the pensions of the civil servants, also as a \% of GDP. My placebo test is, therefore, designed to

\footnotetext{
${ }^{6}$ My measure includes tax revenues from the central government and the autonomous communities since its creation in 1980 s.
} 
check whether my variable of interest loses its explanatory power when the original dependent variable is replaced by a placebo variable (Neumayer and Plümper 2017). Initially, I do not expect civil servants' pensions to be affected by my variable of interest (the interaction term between fiscal capacity and trade openness). Civil servants' pensions are related to the state apparatus (justice, public order, etc.), so that they belong to the non-tradable sector of the economy. I would expect civil servants' pensions to be related (at least partially) to the size of the state but not directly related to globalization. An additional advantage of the pensions of the civil servants as a placebo variable is that it is not a purely random variable. Since they are likely to be related to the size of the government, this should help to account for potential specification errors existing in the baseline model linked, for example, to unobserved factors related to the general evolution of the public sector.

Pensions of the civil servants, however, may be potentially subject to some sort of imitation effect (and can, for example, increase when pensions for the general population increase). In this case, my variable of interest (the interaction term between fiscal capacity and trade openness) would remain positive and the placebo test would be uninformative. The results in table 6 indicate that the coefficients associated to the interaction term between fiscal capacity and trade openness do not remain positive once we introduce our placebo variable and are inconsistent across columns. In columns 1 and 2 (when our original measure of fiscal capacity is used) the estimated coefficients are smaller than in the baseline estimates and are not statistically significant. In columns 5 and 6 (when the ratio associated to the interest on public debt is used as a proxy for fiscal capacity) the coefficients even turn negative and are not statistically significant. Finally, in columns 3 and 4 (when tax revenue over GDP is used as a measure of fiscal capacity) the coefficients are negative and statistically significant, right the opposite of our results in table 3 . Overall these results increase our confidence that the results in table 3 are not completely flawed. 
Table 6. Placebo tests

Dependent Variable: Log(civil servants' pensions as a \% of GDP)

\begin{tabular}{|c|c|c|c|c|c|c|c|c|c|c|c|c|}
\hline & $\begin{array}{l}\text { OLS } \\
(1)\end{array}$ & & $\begin{array}{c}\text { FMOLS } \\
\text { (2) }\end{array}$ & & $\begin{array}{l}\text { OLS } \\
(3)\end{array}$ & & $\begin{array}{c}\text { FMOLS } \\
(4)\end{array}$ & & $\begin{array}{l}\text { OLS } \\
(5)\end{array}$ & & $\begin{array}{c}\text { FMOLS } \\
(6)\end{array}$ & \\
\hline \multirow[t]{2}{*}{ Log(Openness) } & -0.107 & & -0.176 & & 0.827 & $* *$ & 0.891 & $*$ & -0.291 & $*$ & -0.405 & $*$ \\
\hline & (0.169) & & $(0.245)$ & & $(0.287)$ & & $(0.453)$ & & $(0.139)$ & & $(0.210)$ & \\
\hline \multirow[t]{2}{*}{ Log(Openness)*Log(Fiscal Capacity) } & 0.084 & & 0.078 & & & & & & & & & \\
\hline & $(0.098)$ & & $(0.143)$ & & & & & & & & & \\
\hline \multirow[t]{2}{*}{ Log(Fiscal Capacity) } & -0.028 & & 0.076 & & & & & & & & & \\
\hline & $(0.290)$ & & $(0.422)$ & & & & & & & & & \\
\hline \multirow[t]{2}{*}{ Log(Openness)*Log(Tax revenue over GDP) } & & & & & -0.437 & $* * *$ & -0.470 & $* *$ & & & & \\
\hline & & & & & $(0.119)$ & & $(0.187)$ & & & & & \\
\hline \multirow[t]{2}{*}{ Log(Tax revenue over GDP) } & & & & & 1.468 & $* * *$ & 1.525 & $* *$ & & & & \\
\hline & & & & & $(0.418)$ & & $(0.658)$ & & & & & \\
\hline \multirow[t]{2}{*}{$\log \left(\right.$ Openness) ${ }^{*} \log ($ Ratio interest on public debt) } & & & & & & & & & -0.429 & & -0.784 & \\
\hline & & & & & & & & & $(0.514)$ & & (0.770) & \\
\hline \multirow[t]{2}{*}{ Log(Ratio interest on public debt) } & & & & & & & & & 1.236 & & 2.280 & \\
\hline & & & & & & & & & $(1.360)$ & & (2.039) & \\
\hline \multirow[t]{2}{*}{ C } & -7.159 & $* * *$ & -8.330 & $* * *$ & -12.982 & $* * *$ & -14.659 & $* * *$ & -8.777 & $* * *$ & -10.588 & $* * *$ \\
\hline & $(1.664)$ & & $(2.407)$ & & $(1.936)$ & & $(3.057)$ & & $(1.706)$ & & $(2.559)$ & \\
\hline \multirow[t]{2}{*}{ Trend } & -0.012 & $* *$ & -0.013 & $*$ & -0.016 & $* * *$ & -0.016 & $*$ & -0.007 & & -0.006 & \\
\hline & $(0.005)$ & & $(0.008)$ & & $(0.005)$ & & $(0.008)$ & & $(0.005)$ & & $(0.007)$ & \\
\hline Controls & Yes & & Yes & & Yes & & Yes & & Yes & & Yes & \\
\hline Adjusted R-squared & 0.778 & & 0.768 & & 0.772 & & 0.765 & & 0.751 & & 0.742 & \\
\hline S.E. of regression & 0.187 & & 0.192 & & 0.189 & & 0.193 & & 0.198 & & 0.202 & \\
\hline Obs. & 147 & & 147 & & 147 & & 147 & & 147 & & 147 & \\
\hline
\end{tabular}




\section{Conclusions}

Historical evidence suggests that in some countries social policy developed in parallel with high trade openness, whereas in others it did so under trade protectionist policies. Even in some countries, the relationship between globalization and social policy seems to have changed from one period to another. Factors explaining these changes are multiple. This article suggests that fiscal capacity must have been one of them. The econometric results show that in 1850-2000 Spain the impact of trade openness on social spending has been conditional on fiscal capacity. When fiscal capacity has been high, trade openness has been associated with higher social spending. However, when fiscal capacity has been low, trade openness has translated into lower social spending.

This idea that globalization, taxation, and social spending may be interrelated is not new. In the efficiency hypothesis, for example, it is assumed that globalization affects social spending by lowering taxation. I relax this assumption and assume that globalization may reduce fiscal capacity but not necessarily. Fiscal capacity can be high or low ex ante (before trade openness increases); and in some cases, fiscal capacity can remain high after trade openness increases. Open economies may, in fact, adopt a mix of taxes more compatible with international trade (for example, giving more weight to indirect taxes). This seems to have been the case in Spain after the 1960s, when social spending increased in a context of growing trade openness. Later, the fiscal reforms of democracy (that led to the introduction of income tax and VAT and the gradual reduction in compulsory social contributions) permitted social spending growth to continue in a globalized context.

However, in other cases, fiscal capacity can be low ex ante, and can remain low or even diminish when trade openness increases. In these cases, trade globalization will have a negative effect; and social spending could arguably increase more easily in trade-protectionist contexts. This can be particularly the case when, as suggested by Queralt (2017), fiscally weak governments may obtain higher tax compliance by granting trade protection to domestic producers. In this case, trade protectionism would result in a sort of second-best solution suitable for weak states. This seems to have been the case in Spain before the 1960 s. From the beginning of modern social policy, in the late $19^{\text {th }}$ century and early $20^{\text {th }}$ century, social spending grew (slowly) in a context of increasing trade protectionism; and Spanish policy makers resorted to social insurance programs (financed from contributions from employers and employees) to overcome the inability of the government to increase taxation.

Therefore, considering the role of fiscal capacity helps to explain why in some periods in Spain social spending increased along with trade openness, whereas in others social spending increased in contexts of increasing trade protectionism. This could also help to reconcile the conflicting evidence that we often find in both comparative and historical studies on the relationship between trade openness and social spending. But, this is beyond the scope of this paper. 


\section{Bibliography}

Adserà, A. and Boix, C. (2002), "Trade, democracy, and the size of the public sector: the political underpinnings of openness", International Organization, 56(2), 229-262

Alesina, A. and Wacziarg, R. (1998), "Openness, country size and government", Journal of Public Economics, 69, 305-321

Baldwin, P. (1990), The politics of Social Solidarity and the Bourgeois Basis of the European Welfare State, 1875-1975, Cambridge, Cambridge University Press

Betrán, C. and Pons, M.A. (2011), "Labour market response to globalisation: Spain, 18801913", Explorations in Economic History, 48, 169-188

Boix, C.; Miller, M.; and Rosato, S. (2012), "A Complete Data Set of Political Regimes, 18002007", Comparative Political Studies, XX(X), 1-32.

Bradly, D., Seeleib-Kaiser, M. and Beckfield, J. (2005), "Economic Globalization and the Welfare State in Affluent Democracies, 1975-2001", American Sociological Review 70(6), 921-948

Cameron, D.R. (1978), "The expansion of the public economy", American Political Science Review, 72, 1243-1261

Carreras, A. and Tafunell, C. (2018), Entre el Imperio y la Globalización, Barcelona, Crítica

Comín, F. (1996), Historia de hacienda pública II. España 1808-1995, Crítica, Barcelona

Comín, F. and Díaz Fuentes, D. (2005), "Sector público administrativo y Estado del Bienestar", in Carreras, Albert and Tafunell, Xavier (coords.), Estadísticas históricas de España. Siglos XIX y XX, Bilbao, Fundación BBVA, 873-964

Confederación Española de Organizaciones Empresariales (1982a), "Ideas básicas para un programa y posición empresarial sobre la Seguridad Social en España. CEOE (Noviembre 1980)", in Papeles de Economía Española, 12-13 (Documentos), 21-31

Confederación Española de Organizaciones Empresariales (1982b), "Posición de CEOE en materia de Seguridad Social en cumplimiento del punto V.2 del ANE (Enero 1982)", in Papeles de Economía Española, 12-13 (Documentos), 33-53

Cutler, D.M. and Johnson, R. (2004), "The birth and growth of the social insurance state: Explaining old age and medical insurance across countries", Public Choice, 120, 87-121

Chuaire, M.F., Scartascini, C., and Mariano T. (2017), "State capacity and the quality of policies. Revisiting the relationship between openness and government size", Economics \& Politics, 29, $133-156$

Dutton, P.V. (2002), Origins of the French welfare state: the struggle for social reform in France 1914-1947, Cambridge, Cambrigde UP 
Elu, A. (2010), "Las pensiones públicas de vejez en España, 1908-1936", in: Pons, J. and Silvestre, J. (eds.), Los orígenes del Estado del Bienestar en España, 1900-1945: los seguros de accidentes de trabajo, vejez, desempleo y enfermedad, PUZ, Zaragoza

Epifani, P. and Gancia, G. (2009), "Openness, Government Size and Terms of Trade", The Review of Economic Studies 76, 629-668

Espuelas, S. (2012): "Are dictatorships less redistributive? A comparative analysis of social spending in Europe (1950-1980)", European Review of Economic History, 16(2), 211-232

Espuelas, S. (2013): La evolución del gasto social público en España, 1850-2005, Estudios de Historia Económica (63), Madrid: Banco de España

Espuelas, S. (2017), "Political regime and public social spending in Spain: a time series analysis (1850-2000)", Revista de Historia Económica, Journal of Iberian and Latin American Economic History, 35(3), 355-386

Federico, G. and Tena-Junguito, A. (2017), "A tale of two globalizations: gains from trade and openness 1800-2010", Review of World Economics, 153, 601-626

Garret, G. (2001), "Globalization and government spending around the world", Studies in Comparative International Development, 35(4), 3-29

Haggard, S. and Kaufman R. R. (2008), Development, Democracy and Welfare States. Latin America, East Asia and Eastern Europe, Princeton and Oxford, Princeton University Press

Hicks, A. (1999), Social Democracy and Welfare Capitalism, A Century of Income Security Politics, Cornell UP

Huberman, M. (2008), "Ticket to trade: Belgian labour and globalization before 1914", Economic History Review, 61(2), 326-359

Huberman, M. and Lewchuk, W. (2003), "European economic integration and the labour compact, 1850-1913", European Review of Economic History, 7(1), 3-41

Huberman, M. and Meissner, C.M. (2010), "Riding the Wave of Trade: The Rise of Labor Regulation in the Golden Age of Globalization", Journal of Economic History, 70(3), 657-685

Liberati, P. (2007), "Trade openness, capital openness and government size", Journal of Public Policy, 27(2), 215-247

Lindert, P.H. (2004), Growing public social spending and economic growth since the eighteenth century, Cambridge, Cambridge University Press

Linz, J.J.; Montero, J.R.; and Ruiz, A.M. (2005), "Elecciones y política", in Carreras, A. and Tafunell, X. (coords.), Estadísticas históricas de España: siglos XIX y XX. Bilbao: Fundación BBVA

Mares, I. (2003), The Politics of Social Risk: Business and Welfare State Development, Cambridge UP, Cambridge 
Mares, I. (2005), "Social protection around the world. External insecurity, state capacity, and domestic political cleavages", Comparative Political Studies, 38(6), 623-651

Marshall, M.G. and Jaggers, K. (2010), Polity IV Project: Political Regime Characteristics and Transitions, 1800-2009, Fairfax, VA: Center for Systemic Peace, George Mason University.

Mishra, R. (1999). Globalization and the Welfare State. Northampton, MA: Edward Elger

Molinero, C. and Ysas, P. (1998), Productores disciplinados y minorías subversivas. Clase obrera y conflictividad laboral en la España franquista, Madrid, Siglo XXI Editores

Neumayer, E. and Plümper, T. (2017), Robustness Tests for Quantitative Research, Cambridge, Cambridge UP

Nicolau, R. (2005), "Población, salud, y actividad", in Carreras, Albert and Tafunell, Xavier (coords.), Estadísticas históricas de España. Siglos XIX y XX, Bilbao, Fundación BBVA, 1027-1154

Nooruddin, I. and Simmons, J.W. (2009), “Openness, uncertainty, and social spending: implications for the globalization-welfare state debate", International Studies Quarterly, 53, 841-866

Phillips, P.C.B. and Hansen, B.E. (1990), "Statistical Inference in Instrumental Variables Regression with I(1) Processes", Review of Economics Studies, 57, 99-125

Pons, J. and Vilar, M. (2014), El Seguro de salud privado y público en España. Su análisis en perspectiva histórica, PUZ, Zaragoza.

Prados de la Escosura, L. (2003), El progreso económico de España 1850-2000, Bilbao, Fundación BBVA

Prados de la Escosura, L. (2008), "Inequality, poverty and the Kuznets curve in Spain, 18502000", European Review of Economic History, 12, 287-324

Prados de la Escosura, L., Rosés, J.R., and Sanz-Villaroya, I. (2012), "Economic reforms and growth in Franco's Spain", Revista de Historia Económica, Journal of Iberian and Latin American Economic History, 30(1), 45-89

Queralt, D. (2017), "Protection not for sale, but for tax compliance", International Studies Quarterly, 61, 631-641

Rimlinger, G.V. (1971), Welfare policy and industrialization in Europe, America and Russia, Gregg Revivals, UK

Rodrik, D. (1998), "Why do more open economies have bigger governments?", Journal of Political Economy, 106(5), 997-1032

Rodrik, D. (2008), "Second-best institutions", American Economic Review: paper \& proceedings, 98(2), 100-104

Sáenz, E.; Sabaté, M.; and Gadea, M.D. (2013), "Trade openness and public expenditure. The Spanish case, 1960-2000", Public Choice, 154(3), 173-195 
Samaniego, M. (1988), La Unificación de los Seguros Sociales a Debate. La Segunda república, Ministerio de Trabajo y Seguridad Social, Madrid

Silvestre, J. and Pons, J. (2010), "El seguro de accidentes del trabajo, 1900-1935. El alcance de las indemnizaciones, la asistencia sanitaria y la prevención", in: Pons, J. and Silvestre, J. (eds.), Los orígenes del Estado del Bienestar en España, 1900-1945: los seguros de accidentes de trabajo, vejez, desempleo y enfermedad, PUZ, Zaragoza

Tena, A. (2005): "Sector exterior", in Carreras, A. and Tafunell, X. (coords.), Estadísticas históricas de España: siglos XIX y XX. Bilbao: Fundación BBVA

Tena, A. (1999), "Un nuevo perfil del proteccionismo español durante la Restauración, 18751930", Revista de Historia Económica, 3, 579-621

Tirado, D.A. (1996), "Protección arancelaria y evolución de la economía española durante la Restauración: un ensayo interpretativo", Revista de Historia Industrial, 9, 53-81

Torregrosa-Hetaland, S. (2015), "Did democracy bring redistribution? Insights from the Spanish tax system, 1960-90", European Review of Economic History, 19, 294-315

Tusell, J. (2005), Dictadura franquista y democracia, 1939-2004, Barcelona, Crítica

Urquijo, J.R. (2001): Gobiernos y ministros españoles (1808-2000). Madrid: CSIC 